\title{
アルカリ土類炭酸塩添加による溶融炭酸塩燃料電池 酸化ニッケルカソードの溶出低減
}

\author{
小川 斗*, 大図 秀行', 村田 謙二, 城上 保 $^{\dagger}$
}

\section{Reduction of NiO Cathode Loss in Molten Carbonate Fuel Cell with the Addition of Alkaline-earth Carbonates}

Takashi OGAWA*, Hideyuki OOZU ${ }^{\dagger}$, Kenji MURATA and Tamotsu ShIROGAMI ${ }^{+}$

Abstract

The instability of the Ni0 cathode is one of the major technical problems In MCFC (Molten Carbonate Fuel Cel1) development. Addition of the small amounts of alkaline-earth carbonate salts to the electrolyte is found effective to decrease the Ni dissolution from the cathode. Post test analysis of the cells, af ter about 3000 hour operations, proved that the amounts of $\mathrm{Ni}$ compounds in the electrolytes containing ei ther $5 \mathrm{molK} \mathrm{MgCO}_{3}$ or 5 $\mathrm{BaCO}_{3}$ are less than $1 / 3$ of that in the electrolyte without alkaline-earth carbonate.

\section{1. 绪言}

溶能炭酸㙁然料電池 (M C F C) 発電プラントは高勃 率が期待できるので、米国のみならずわが国でも開発が 進めらている1。

しかし、胃状はMCF C 本体を実用に供し得る寿命、 すなわちユーザーが必要とする寿命を達成する見通しを 得るに至っていない。この要因として、電解質ロス、ア ノードのクリープ、セパレータの腐食等が指畝されてき $\star^{2)}$ 。

ところが、近年、1 0 ata ${ }^{3)}$ の高圧下で運転試路され た溶融炭酸塩然料電池セ儿の電解質層中に多量の金属二

株式会社東芝総合研究所エネルキー機器研究所

（テ210 川崎市川崎区浮島町 4-1)Toshiba Corporation

Toshiba Research and Development Center (4-1,Ukishina-cho, Kawasaki-ku, Kawasaki 210)

+ 株式会社東芝総合研究所金属セラミック材料研究所 （下210 川崎市幸区小向東芝町1)Toshiba Corporation Toshiba Research and Development Center

(1. Konukai toshiba-cho. Saivai-ku, Kawasaki 210)

++株式会社東芝小向工場宇宙開発事業部

（テ210川崎市幸区小向東芝町1)Toshiba Corporation Konukai Space Prograns Div. ( 1 . Konukaitoshibacho. Saiwai-ku, Kawasaki, 210)

Key Words: Molten Carbonate. Fuel Ce11. NiO Cathode. Dissolution
ッケルが析出していることが钼察され゙)、酸化ニッヶル カソードも耐久性が不十分であることが判明した。

酸化ニッケルは、カソードの副反忘で $\mathrm{N} \mathrm{i}^{2+}$ イオンと なり、これが電解質首中をアノード方向へ搪敞移勤し、

アノード侧から拡散してきた水亲によって退元され、金 属 $\mathrm{N}$ i として折出するので、カソードの酸化ニッケルは 電解質融体中での盷和溶解度に支配されることなく多量 に溶出すると報告されている4)。さらに、この溶出は電 解算中における $\mathrm{N} \mathrm{i}^{2+}$ イオンの应敉律速なbのとされて (る

そこで我々は、N $\mathrm{i}^{2+}$ イオンの拡散を抑制する方法を 検討し、その1つとして電解質へのアルカリ土類炭酸醏 の添加を行い、これが䤒化ニッケルカソードの溶出低減 に効果があることを確認したので埌告する。

\section{2.実駼方法}

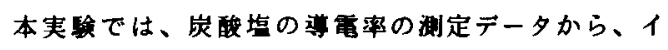
オン伝䙷性に影要が生じない籍用、すなわち 5 および 10 mo1\%のアルカリ土類炭酸堭を 62 mo1kL i $2 \mathrm{C} \mathrm{O}_{3}$ - 38 m01\%K ${ }_{2} \mathrm{CO}_{3}$ に添加して電解質とした。

電解算屡として $35 \mathrm{wtX} \gamma-\mathrm{L}$ i A $1 \mathrm{O}_{2}-65 \mathrm{wt}$

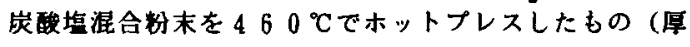
さ2ッ）を用いた。被晚セルは上記の電解質届と $\mathrm{N} \mathrm{i}$ - 3 vtX C r 多孔質焼結体アノードと、ニッケル多れ 質焼結体カソードとを用いて㭋成した。セルの大き さは、有效面皘 $10 \mathrm{cq}^{2}$ である。このセルを $650{ }^{\circ} \mathrm{C}$, 


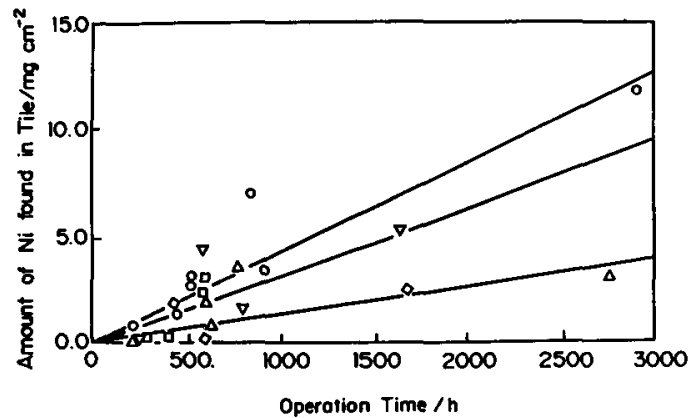

Fig. 1 Amounts of $\mathrm{Ni}$ deposits in the tiles with 5 nol\% alkaline-earth carbonates added $\left(T-650{ }^{\circ} \mathrm{C}\right.$, $\mathrm{P}\left(\mathrm{CO}_{2}\right)=0.3$ at and $\mathrm{i}=0.15 \mathrm{\Lambda} / \mathrm{cm}^{2}$ )

$O:$ none, $\triangle: \mathrm{BaCO}_{3}, \square: \mathrm{SrCO}_{3}, \nabla: \mathrm{CaCO}_{3}$.

$\diamond: \mathrm{MgCO}_{3}$

1 atmの条件下で、然料として 72 vol\%H $2-18$ vol\% $\mathrm{C} \mathrm{O}_{2}-10$ vol\&H ${ }_{2}$ O混合ガスを、酸化䋛として 70 vo1\%A i r -30 vol\%C O 2 混合ガスをそれぞれ 100 $\mathrm{ml} / \mathrm{min}, 200 \mathrm{ml} / \mathrm{min}$ (ドライベース) 供給して 150 $\mathrm{aA} / \mathrm{cr}^{2}$ の定電流で通枟した。運転終了後、分解して電 解質層を取り出し、原子吸光分析により電解質層に溶出 しているニッケル量を求めた。また、エネルギー分散型 $\mathrm{X}$ 線分析により電解質展中でのニッケルの湌度分布（但 し、 $\mathrm{N}$ i， $\mathrm{N}$ i O, $\mathrm{N}$ i C O 3 の区別はできない)を求 めた。

なお、比较のため 62 mo1\%L i $\mathrm{CO}_{3}-38$ no1k $\mathrm{K}_{2} \mathrm{C} \mathrm{O}_{3}$ 共融混合塩を電解質とする場合についても実 唋を行った。

\section{3、結果}

$3.1 ニ ッ$ ニ溶出昷

アルカリ土類炭酸坦を5 501 添加した電解質使用七 ルの通鉣時間とニッケル溶出量との関係をFig.1 に示 す。Fig.1に明らかなようにニッケル溶出速度は、無 添加電解質使用セルの4.25 $\mu \mathrm{g} \cdot \mathrm{cm}^{-2} \mathrm{~h}-1$ に対して、

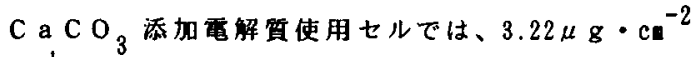
$\mathrm{h}^{-1}$, $\mathrm{BaC} \mathrm{O} ， \mathrm{MgCO}_{3}$ 添加電解質使用七ルでは、 $1.34 \mu \mathrm{g} \cdot \mathrm{ca}^{-2} \mathrm{~h}^{-1}$ である。したがって、電解質に 5

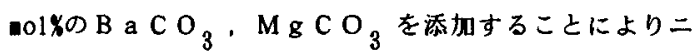
ッケル溶出速度を1/3 以下にすることができたと判断で きる。

アルカリ土類炭酸醏を 10 -01添加した電解質使用七 ルの運伝時間とニッケル浴出量との関係をFig.2 に示す。 アルカリ土類炭酸塩を 10 -01添加した電解質使用セル はいずれもニッケル溶出速度が $3.33 \mu \mathrm{g} \cdot \mathrm{cm}^{-2} \mathrm{~h}{ }^{-1}$ であ

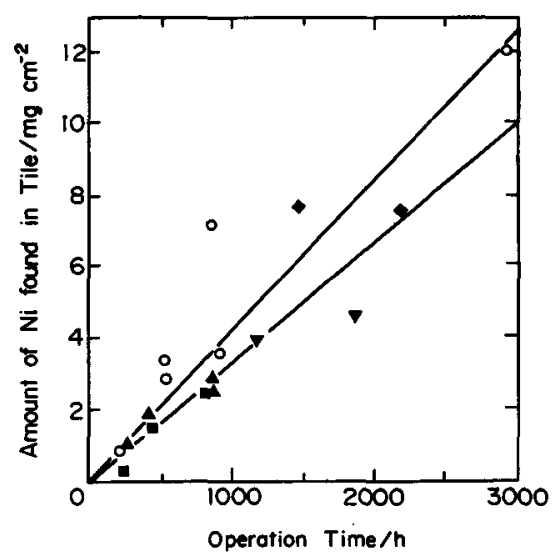

Fig. 2 Awounts of $\mathrm{Ni}$ deposits in the tiles with 10 mol\% alkaline-earth carbonates added ( T-650 ${ }^{\circ} \mathrm{C}$, $\mathrm{P}\left(\mathrm{CO}_{2}\right)=0.3$ at and $\left.\mathrm{i}=0.15 \mathrm{~A} / \mathrm{cm}^{2}\right)$

$$
\begin{aligned}
& O: \text { none, } \triangle: \mathrm{BaCO}_{3}, \mathbf{Z}: \mathrm{SrCO}_{3}, \nabla: \mathrm{CaCO}_{3} \text {. } \\
& \square: \mathrm{MgCO}_{3}
\end{aligned}
$$

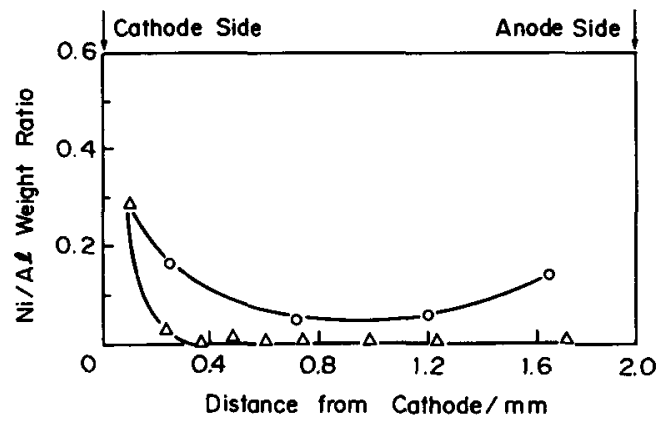

Fig. 3 Ni distributions in the tiles containing alkal ine-earth carbonates $\left(\mathrm{T}-650^{\circ} \mathrm{C}, \mathrm{P}\left(\mathrm{CO}_{2}\right)=0.3\right.$ ate and $\mathrm{i}=0.15 \mathrm{~A} / \mathrm{cm}^{2}$ )

$O:$ none $(918 \mathrm{~h}), \Delta: 5=01 \times \mathrm{CaCO}_{3}(800 \mathrm{~h})$

る。したがって、添加量を5no1犺ら 10 no1犺增やし ても、ニッケル溶出速度は、 $\mathrm{C}$ a $\mathrm{C} \mathrm{O}_{3}$ 添加では変化せ ず、 $\mathrm{B} \mathrm{a} \mathrm{C} \mathrm{O}{ }_{3}, \mathrm{Mg} \mathrm{CO}_{3}$ 添加では逆に增大すると判 断される。

\section{2 二ッケルの沙度分布}

Fig.3に約 800 時間運転したときのニッケルの電解 質首中の湿度分布を示す。なお、ニッケルの淇度は電解 質冨中に均一に分布する L i A $10_{2}$ 中のA 1 量に対す る比として求めた。無添加の電解質では、既にニッケル がアノド付近で析出しているのに対し、 $\mathrm{Ca} \mathrm{C} \mathrm{O}$ 5 no1添加した電解質ではニッケルはカソード近傍（カ ソードから0.4 的末满の筑囲)にしか存在しない。また、 


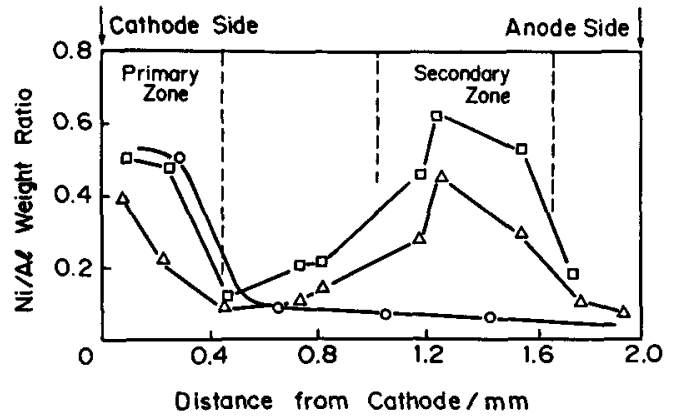

Fig. 4 Ni distributions in the tlles containing alkaline-earth carbonates $\left(\mathrm{T}=650^{\circ} \mathrm{C}, \mathrm{P}\left(\mathrm{CO}_{2}\right)=0.3\right.$ at and $\mathrm{i}=0.15 \mathrm{~A} / \mathrm{cm}^{2}$ )

$O: 5.01 \% \mathrm{BaCO}_{3}(2752 \mathrm{~h}), \triangle: 10=1 \% \mathrm{CaCO}_{3}(1880 \mathrm{~h})$, $\square: 10$-ol\% $\mathrm{MgCO}_{3}(2135 \mathrm{~h})$

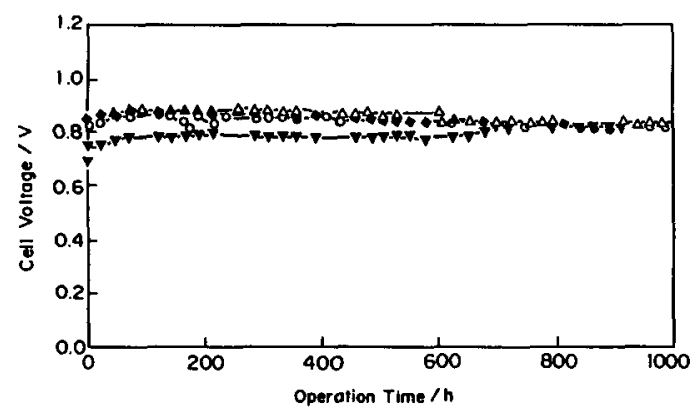

Fig. 5 A comparison of cell perforances at $650{ }^{\circ} \mathrm{C}$. 1 atd and $0.15 \mathrm{~A} / \mathrm{cm}^{2}$ (Fuel:72 vol\% $\mathrm{H}_{2}-18$ vol\% $\mathrm{CO}_{2}-10$ vol\% $\mathrm{H}_{2} 0.0 \mathrm{x} .: 70$ vol\% Air-30 vol\% $\mathrm{CO}_{2}$ ): cells with the electrolytes containing alkalineearth carbonate salts

$O$ : none, $\triangle: 5$ mol\% $\mathrm{BaCO}_{3}, \nabla: 10$.01\% $\mathrm{CaCO}_{3}$, $\bullet: 10$ nol\% $\mathrm{MgCO}_{3}$

カソード・電解質屏境界付近での、両者のニッケル浱度 ははぼ一致している。

Fig.4に約2000 3000時間運転したときのニッケルの 電解算㕌中の搌度分布を示す。 $\mathrm{M} \mathrm{g} \mathrm{CO}_{3}, \mathrm{C} \mathrm{a} \mathrm{C} \mathrm{O}_{3}$ を 10 001婖加した電解質では、カソード近傍とアノー ド近管との両方でニッケル浱度が高くなっている。これ に対し、B a $\mathrm{CO}_{3}$ を 5 mo1㮇加した電解質では、カソ 一ド近傍にのみニッケル䈨度のピークが存在する。また、 カソード・電解質層境界付近での、3者のニッケル湌度 ははばー致している。

3.3 セル性能

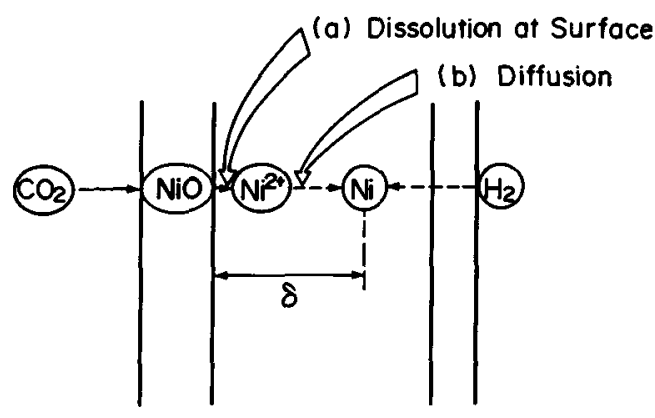

Cathode Electrolyte Anode

Tile

Fig. 6 a model of $\mathrm{Ni}$ dissolution from the cathode

アルカリ土類炭酸塩の電解質への添加がセル性能に及

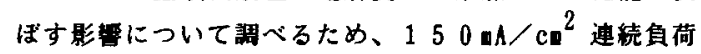
を印加し、セル電圧の経時変化を調べた。その結果を Fig.5 に示す。電解質にアルカリ土類炭酸塩を添加して も、雉加の電解筫使用セルと同侎に $150 \mathrm{nh} / \mathrm{ca}^{2}$ 連 続負荷時に対し、0.8〜0.9Vのセル電圧が安定して得ら れた。

\section{4.考察}

酸化ニッケルの溶出機構としてFig.6 に示すプロセス か考えられている。すなわち、溶融炭酸塩中への酸化二 ッケルの飽和溶解度が芧囲気の二酸化炭莱ガス压力に比 例すること吕から、カソード側で反応

$$
\mathrm{NiO}+\mathrm{CO}_{2} \rightarrow \mathrm{Ni}^{2+}+\mathrm{CO}_{3}^{2-}
$$

によって $\mathrm{i}^{2+}$ イオンして電解質に溶解する。次に溶 解した $\mathrm{N} \mathrm{i}^{2+}$ イオンがアノード方向人摭散移動し、アノ 一ド側から拡散してきた水素によって還元され、金属 Niとして析出する。したがってニッケルの溶出量につ いて下記の関係式が与えられている ${ }^{6.7) 。 ~}$

$$
\begin{aligned}
M(N) & =\frac{D\left(\mathrm{Ni}^{2+}\right) \cdot \mathrm{C}\left(\mathrm{Ni}^{2+}\right) \cdot \mathrm{t}}{(\mathrm{n} / \mathrm{f}) \delta} \\
& =\frac{\mathrm{D}\left(\mathrm{Ni}^{2+}\right) \cdot \mathrm{K}(\mathrm{Ni}) \cdot \mathrm{P}\left(\mathrm{CO}_{2}\right) \cdot \mathrm{t}}{(\mathrm{n} / \mathrm{f}) \delta}
\end{aligned}
$$

$\mathrm{M}(\mathrm{Ni}) \quad$ : Ni の溶出量 $\left(\mathrm{ag} / \mathrm{cm}^{2}\right)$

$\mathrm{D}\left(\mathrm{Ni}^{2+}\right): \mathrm{Ni}^{2+}$ の拡散係数 $\left(\mathrm{cm}^{2} / \mathrm{s}\right)$

$\mathrm{C}\left(\mathrm{Ni}^{2+}\right): \mathrm{N} \mathrm{i}^{2+}$ の溶解度 $\left(\mathrm{gg} / \mathrm{cs}^{3}\right)$

$\mathbf{t}$ : 運転時間 $(s)$

n : : 屈曲係数 (tortuosity factor ${ }^{8)}$ )

f : 電解質の体榬比 


$$
\begin{aligned}
& \delta \quad: \mathrm{N} \mathrm{i}^{2+} \text { の拡散距篮 }(\mathrm{cm}) \\
& \mathrm{K}(\mathrm{Ni}) \text { : 反店 (1) の平衡定数 } \\
& \mathrm{P}\left(\mathrm{CO}_{2}\right) \text { : 二醩化炭素分圧 (atm) }
\end{aligned}
$$

Fig.4 に示した $\mathrm{MgCO}_{3}, \mathrm{CaCO}_{3}$ を 10 nol\%添 加した電解質板中のニッケルの濃度分布はカソード近傍 で単調減少した後にアノード近傍で高くなる双峰型であ る。このことはカソード側で溶出する酸化ニッケルは一 旦、反応(1) を経由してN i ${ }^{2+}$ イオンとなり、電解質中 を拡散してアノード近傍に達し、そこで水素により㟫元 して析出するという機構が钦いていることを示しており、 Voge1 らの提起した酸化ニッケルの溶出機構 ${ }^{6,7)}$ 上合致 している。

したがって、酸化ニッケルカソードの溶出量を低減す るためには（2）式を考雷すると、

(1) 低 $\mathrm{P}\left(\mathrm{CO}_{2}\right)$ 下で運転する

（2） $\mathrm{n} / \mathrm{f}$ の大きな電解質層を用いる。

(3) $\mathrm{N} \mathrm{i}^{2+}$ の拡散係数が小さい電解質を用いる。

(4) $\mathrm{N} \mathrm{i}{ }^{2+}$ の溶解度が小さい電解質を用いる。

の 4 方法があることがわかる。このうち、(1) では開路

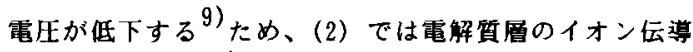
抵抗が增大する ${ }^{10 ）}$ ため、上もに電池電圧が低下するの で使用できない。したがって、（3）または（4）を满たす 新規電解質を用いることが必要である。

ところで、シリカカラス中での $\mathrm{Cu}^{2+}$ の拡散が $\mathrm{C}$ a $\mathrm{O}$ 成分を增やすと抑制されること11）、炭酸りチウム一炭 酸カリウムー炭酸ナトリウム共融混合塩にアルカリ土類

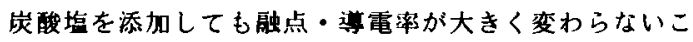
$と^{12)}$ が知られている。そこで我々は、導電㴋が低下 しない籍囲で電解質にアルカリ土類炭酸塩を添加して $\mathrm{N} \mathrm{i}^{2+}$ の拡散の抑制を武み、上述の結果を得た。

なお、Fig.3.4においてカソード・電解質層境界にお

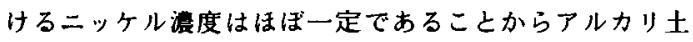
類炭酸醏を添加した電解質への酸化ニッケルの溶解度は 変化していないと推定される。そこで、N i ${ }^{2+}$ イオンの 挙趿を考察してみた。

初期のカソード近傍にのみニッケル錪度のピークがあ る間、すなわち、Fig３．4に見られるように発電開始直 後で、 $\mathrm{N} \mathrm{i}^{2+}$ イオンがカソード侧からアノード側へ拡散 している時点では、電解質層中にニッケルは $\mathrm{i}^{2+}$ イオ ンの形でのみ存在して、カソード側からアノード側へ拡 散居が広がっており、

$$
\left(\mathrm{D}\left(\mathrm{Ni}^{2+}\right) \cdot \mathrm{t}\right)^{0.5} \propto \mathrm{n} \delta
$$

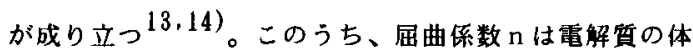
皘比 $\mathrm{f}$ に依存する $^{|0\rangle}$ 。ところで本報の実呀鉴囲ではア ルカリ土類炭酸塩の添加量が少ないので、炭酸壏の密度
泝化は小さく $\mathrm{f} は$ ばー定であり、nは一定と見なせる。 Fig.3.4 のデータから(3) 式を使って、アルカリ土類宸 酸塩添加電解質中の $\mathrm{N} \mathrm{i}^{2+}$ の拡散湶数之無添加電解質 中の $\mathrm{N} \mathrm{i}^{2+}$ の拡散係数どの比を求めると、 $\mathrm{CaC} \mathrm{O}_{3}$ 5 gol添加のとき0.79， B a C O 5 .018添加のとき 0.40 となった。

一方、アルカリ土類岸酸塩添加電解質使用七ルのニッ ケル溶出速度と無添加電解質使用セルのニッケル溶出速 度との比を求める上、 $\mathrm{C} \mathrm{a} \mathrm{C} \mathrm{O} 5$ m01添加電解質使用 セルで0.76， B a C O 5 m01添加電解質使用セル0.32 となった。両者が良く一致することから、電解質へのア ルカリ土類炭酸塩の添加によるニッケル溶出速度の低減 はN i ${ }^{2+}$ イオンの拡散が抑制されるためであると考えら れる

\section{5. 結 論}

a . 電解質へのアルカリ土類炭酸淖の添加は酸化ニッケ ルカソード溶出速度の低娍に有効であり、5 rol $\%$ の $\mathrm{B} \mathrm{a} \mathrm{C} \mathrm{O} 3$ あるいは $\mathrm{g} \mathrm{CO}_{3}$ を添加すると $1 / 3$ 以下 になった。

b．アルカリ土類炭酸塩の添加量を 5 mo1\%から 10 上ol\% へ增やしても、ニッケル溶出速度は $\mathrm{C} \mathrm{a} \mathrm{C} \mathrm{O} 3$ では変 わらず、B a C O 3 および g C O た。

c．アルカリ土類炭酸境の添加はニッケルイオンの拡散 を抑制する効果があった。

\section{文献}

1) 児玉晧堆，溶融壏，28，7（1985）

2) J.R. Selman and L.G. Marianowski, Molten Salt Technology (D.G. Lovering, ed.), p.323-393. Plenum Press. New York (1982)

3) 1 atm $-101.325 \mathrm{kPa}$

4) H.R. Kunz, 1982 National Fuel Cel1 Sesinar Abstracts. p.116-119, Courtesy Associates. Inc.. Washington. D.C.

5）太田健一郎，光島重徳，加藤茂美，渡辺雅人，神谷 信行, 電気化学, 56, 647 (1988)

6) V.M. Vogel, L.J. Bregoli, H.R. Kunz and S.N. Saith, Molten Carbonate Fuel Cell Technology (J.R. Selman and T.D. Claar ed.), p.443-451, The Electrochea. Soc., Inc., Pennington. NJ (1984)

7) General Electric Conpany, DoE/ET/17019-20-vol. 1. p. 4-149 4-174 (1985)

8) K. Micka and M. Svata. J. Power Sources, ․․, 
$167(1978)$

9) Institute of Gas Technology, C00-1545-T1, p.59 (1980)

10) R.E. De La Rue and C.K. Tobias, J. Electroches. Soc.. 106, 827 (1959)

11) S. Sakka. K. Kaniya, T. Yoko and K. Kato, Proc. 1st International Synp. on Molten Salt Chew. and Technology, p.137-140, Apri1 20-22.
1983, Kyoto, Japan

12) O.K. Davtyan, G.A. Teterin and M.V. Uninski i. Sov. Electrochea.. 6. 773 (1970)

13) J. Crank. The Mathematicics of Diffusion, 2nd ed., p. 20-21, Clarendon Press, Oxford (1979)

14) A.J. Bard and L.R. Faulkner. Electrochenical Methods. Fundanentals and Applications, p.667668. John Wiley \& Sons, Inc.. New York (1980) 